medRxiv preprint doi: https://doi.org/10.1101/2020.06.02.20118489; this version posted June 11, 2021. The copyright holder for this preprint (which was not certified by peer review) is the author/funder, who has granted medRxiv a license to display the preprint in perpetuity.

It is made available under a CC-BY 4.0 International license.

\title{
Development and implementation of a customised rapid syndromic diagnostic test for severe pneumonia
}

Vilas Navapurkar ${ }^{\S 1}$, Josefin Bartholdson Scott ${ }^{\S 2}$, Mailis Maes ${ }^{2}$, Thomas P Hellyer ${ }^{3,4}$, Ellen Higginson $^{2}$, Sally Forrest ${ }^{2}$, Joana Pereira-Dias ${ }^{2}$, Surendra Parmar ${ }^{5}$, Emma Heasman-Hunt ${ }^{5}$, Petra Polgarova ${ }^{1}$, Jo Brown ${ }^{1}$, Lissamma Titti ${ }^{1}$, William PW Smith ${ }^{6}$, Jonathan Scott ${ }^{3}$, Anthony Rostron $^{3}$, Matthew Routledge ${ }^{5,7}$, David Sapsford ${ }^{8}$, M.Estée Török ${ }^{9,10}$, Ronan McMullan ${ }^{11}$ David A Enoch ${ }^{5}$, Vanessa Wong ${ }^{5,7}$, The VAPrapid investigators, Martin D Curran $^{5}$, Nicholas M Brown ${ }^{5}$ A John Simpson ${ }^{3,4}$, Jurgen Herre ${ }^{12}$, Gordon Dougan ${ }^{2}$, Andrew Conway Morris ${ }^{1,13^{*}}$

1. John V Farman Intensive Care Unit, Addenbrooke's Hospital, Cambridge, United Kingdom

2. Cambridge Institute of Therapeutic Immunology \& Infectious Disease, Department of Medicine, University of Cambridge, Cambridge, United Kingdom

3. Translational and Clinical Research Institute, Newcastle University, United Kingdom

4. Newcastle upon Tyne Hospitals NHS Foundation Trust, Newcastle, United Kingdom

5. Clinical Microbiology and Public Health Laboratory, Public Health England, Cambridge, United Kingdom

6. Clinical School, University of Cambridge, Cambridge, United Kingdom

7. Infectious Diseases, Addenbrooke's Hospital, Cambridge, United Kingdom

8. Pharmacy Department, Addenbrooke's Hospital, Cambridge, United Kingdom

9. Department of Medicine, University of Cambridge

10. Department of Microbiology, Cambridge University Hospitals NHS Foundation Trust, United Kingdom

11. Wellcome-Wolfson Institute for Experimental Medicine, Queen's University Belfast, United Kingdom

12. Respiratory Medicine, Addenbrooke's Hospital, Cambridge, United Kingdom

13. Division of Anaesthesia, Department of Medicine, University of Cambridge, Cambridge, United Kingdom

${ }^{\S}$ The identified authors contributed equally to the manuscript.

*Address for correspondence

Andrew Conway Morris

Division of Anaesthesia

Department of Medicine

Level 4, Addenbrooke's Hospital

Hills Road

Cambridge

CB2 0QQ

Email: ac926@cam.ac.uk

Phone: +44 (0)1223 217889

Word count: abstract 257, manuscript 2998

Running title: Rapid molecular diagnostic in severe pneumonia 
medRxiv preprint doi: https://doi.org/10.1101/2020.06.02.20118489; this version posted June 11, 2021. The copyright holder for this preprint (which was not certified by peer review) is the author/funder, who has granted medRxiv a license to display the preprint in perpetuity.

It is made available under a CC-BY 4.0 International license .

\section{Declarations}

Ethical approval and consent to participate: Written informed consent was obtained from patients or their proxy decision maker for studies where samples were obtained, where participants regained capacity retrospective consent was sought. The samples for the retrospective study were obtained from the VAPrapid study (ref 15) which was approved by the England and Northern Ireland (13/LO/065) and Scotland (13/SS/0074) National Research Ethics Service committees and sponsored by Newcastle upon Tyne Hospitals NHS Foundation Trust.

The prospective study was approved by the Leeds East Research Ethics Committee (17/YH/0286) Cambridge University Hospitals NHS Foundation Trust was the sponsor.

The assessment of routinely collected data from the comparator group received a consent waiver and was conducted under a protocol approved by the institutional review board (A095506).

Consent for publication: no individual patient data presented, not required

Availability of data: Microbial sequencing data is available from European Nucleotide Archive (ENA) with study accession numbers ERP111277, ERP111280, ERP112277, and ERP018622. Patient data is not publicly available for confidentiality reasons, but anonymised data can be obtained through contact with the corresponding author, subject to appropriate data sharing agreements being in place.

Competing interests: MDC is the inventor on a patent held by the Secretary of State for Health (UK Government) EP2788503, which covers some of the genetic sequences used in this study. VN is a founder, Director and shareholder in Cambridge Infection Diagnostics Ltd (CID Ltd) which is a commercial company aimed at developing molecular diagnostics in infection and antimicrobial and AMR stewardship. NMB, GD and ACM are members of the Scientific Advisory Board of Cambridge Infection Diagnostics Ltd (CID Ltd). All other authors declare no conflict of interest.

\section{Funding}

The study was funded by Addenbrooke's Charitable Trust and the NIHR Cambridge Biomedical Resource Centre (Grant 18135 to Professor Dougan). Dr Török is supported by a Clinician Scientist Fellowship (funded by the Academy of Medical Sciences and the Health Foundation) and by the NIHR Biomedical Research Centre. Dr Conway Morris was supported by a Clinical Research Career Development Fellowship from the Wellcome Trust at the time of the work (WT 2055214/Z/16/Z) and is currently supported by an MRC Clinician Scientist Fellowship (MR/V006118/1). The metagenomic sequencing was funded by the Wellcome Trust. VAPrapid was funded Health Innovation Challenge Fund(HICF510-078;094949/Z/10/X), a parallel funding partnership between the UK Department of Health and Wellcome Trust. Professor Simpson is a National Institute for Health Research (NIHR) Senior Investigator. The views expressed in this publication are those of the authors and not necessarily those of the UK Department of Health or Wellcome Trust. The funders had no role in the analysis of data or decision to publish. The corresponding author had full access to all the data in the study and had final responsibility for the decision to submit for publication. 


\section{Acknowledgements}

The VAPrapid investigators are Prof DF McAuley, Prof TS Walsh, Dr N Anderson, Dr S Singh, Prof P Dark, Dr A Roy, Prof GD Perkins, Ms L Emerson, Prof B Blackwood, Dr SE Wright, D K Kefala, Prof CM O’Kane, Dr SV Baudouin, Dr RL Patterson, Dr A Agus, Dr J Bannard-Smith, Dr NM Robbin, Prof ID Welters, Dr C Bassford, Dr B Yates, Dr C Spencer, Dr SK Laha, Dr J Hulme, Prof S Bonner, Dr V Linnett, Dr J Sonsken, Dr Van Den Broeck, Dr G Boschman, Mr DWJ Kennan, Dr AJ Allan, Mr G Phair, Ms J Parker and Dr SA Bowett.

The authors thank the consultant intensivists of the John V Farman Intensive Care Unit, Drs P Bradley, P Featherstone, S Ford, M Georgieva, A Johnston, R Mahroof, J Martin, J Preller, K Patel, C Summers, M Trivedi, J Varley, Pharmacist L Radford, the nursing and physiotherapy teams who managed the patients, and the patients and their families who consented to the study. We also thank Torsten Seemann for access to his Kraken database.

\section{Keywords: Antimicrobial stewardship ,Critical Care, Molecular pathology, Pneumonia}

Contribution (CReDIT)

VN -Conceptualisation, resources, investigation, writing-review and editing, project administration, funding acquisition, supervision.

JBS -resources, investigation, data curation, formal analysis, writing-original draft.

MM-resources, investigation, writing-review and editing.

TH-resources, investigation, writing-review and editing

EH-investigation, writing-review and editing.

SF-investigation, writing-review and editing.

JD-investigation, writing-review and editing.

SP-investigation, writing-review and editing.

EHH-investigation, writing-review and editing.

PP-investigation, data curation writing-review and editing.

JB-investigation, data curation writing-review and editing.

LT-investigation, data curation writing-review and editing.

WS- data curation writing-review and editing

JS- resources, investigation, writing-review and editing

AR- resources, investigation, writing-review and editing

MR-data curation writing-review and editing.

DS-data curation writing-review and editing.

MET-conceptualisation, investigation, data curation writing-review and editing

DE-investigation, writing-review and editing.

VW-formal analysis, investigation, data curation writing-review and editing.

MDC-Conceptualisation, resources, investigation, writing-review and editing, project administration, funding acquisition, supervision.

NB-Conceptualisation, resources, investigation, writing-review and editing, project administration, supervision. AJS- resources, investigation, writing-review and editing

JH-Conceptualisation, resources, investigation, writing-review and editing.

GD-Conceptualisation, resources, investigation, writing-review and editing, project administration, funding acquisition, supervision.

ACM-Conceptualisation, methodology, resources, investigation, writing-original draft, project administration, formal analysis, funding acquisition, supervision. 


\begin{abstract}
Background

Microbial cultures for the diagnosis of pneumonia take several days to return a result, and are frequently negative, compromising antimicrobial stewardship. The objective of this study was to establish the performance of a syndromic molecular diagnostic approach, using a custom TaqMan array card (TAC) covering 52 respiratory pathogens, and assess its impact on antimicrobial prescribing.
\end{abstract}

\title{
Methods
}

The TAC was validated against a retrospective multi-centre cohort of broncho-alveolar lavage samples. The TAC was assessed prospectively in patients undergoing investigation for suspected pneumonia, with a comparator cohort formed of patients investigated when the TAC laboratory team were unavailable.

Co-primary outcomes were sensitivity compared to conventional microbiology and, for the prospective study, time to result. Metagenomic sequencing was performed to validate findings in prospective samples. Antibiotic free days (AFD) were compared between the study cohort and comparator group.

\section{Results}

128 stored samples were tested, with sensitivity of 97\% (95\% CI 88-100\%). Prospectively 95 patients were tested by TAC, with 71 forming the comparator group. TAC returned results 51 hours (IQR 41-69 hours) faster than culture and with sensitivity of 92\% (95\% CI 83-98\%) compared to conventional microbiology. $94 \%$ of organisms identified by sequencing were detected by TAC. There was a significant difference in the distribution of AFDs with more AFDs in the TAC group ( $\mathrm{p}=0.02)$. TAC group were more likely to experience antimicrobial de-escalation (OR 2.9 (95\%1.5-5.5).

\section{Conclusions}

Implementation of a syndromic molecular diagnostic approach to pneumonia led to faster results, with high sensitivity and impact on antibiotic prescribing.

Trial registration: The prospective study was registered with clinicaltrials.gov NCT03996330 
medRxiv preprint doi: https://doi.org/10.1101/2020.06.02.20118489; this version posted June 11, 2021. The copyright holder for this preprint (which was not certified by peer review) is the author/funder, who has granted medRxiv a license to display the preprint in perpetuity.

It is made available under a CC-BY 4.0 International license.

\section{Introduction}

2 For many decades the diagnosis of infectious diseases has relied on a combination of clinical

3 assessment and microbiological culture. However, cultures are frequently negative ${ }^{1,2}$ and

4 can take several days to return a result. ${ }^{3}$ Optimising antimicrobial therapy can be challenging,

5 especially in patients who are at risk of multidrug resistant organisms. ${ }^{2}$ In critically ill

6 patients, this frequently results in the empiric use of broad-spectrum agents, with predictable

7 consequences for antimicrobial resistance and other forms of antimicrobial-related harm. ${ }^{4}$

8 Conversely, failure to identify the causative organism can lead to inappropriate antimicrobial

9 therapy, which is associated with poor outcomes. ${ }^{5}$

11 Pneumonia amongst intubated and mechanically ventilated, critically ill patients can be

12 especially difficult to diagnose. ${ }^{6}$ Most critically ill patients are systemically inflamed, ${ }^{7}$

13 clinical examination is unreliable ${ }^{8}$ and there are multiple causes of radiographic lung

14 infiltrates most of which are non-infectious. ${ }^{9,10}$

16 The development of host-based biomarkers for infection, such as C-reactive protein, ${ }^{11}$

17 procalcitonin, ${ }^{12}$ and alveolar cytokine concentrations ${ }^{13}$ have been advanced as useful

18 measures to help rationalise antimicrobial use. However, their utility in the diagnosis ${ }^{11,12}$ and

19 antimicrobial stewardship ${ }^{14,15}$ of pneumonia has been challenged.

21 There is, therefore, a pressing need for rapid, sensitive, multi-pathogen-focussed diagnostic

22 tests for pneumonia ${ }^{16}$. TaqMan array cards (TAC) enable the conduct of multiple

23 simultaneous single-plex real-time polymerase chain reaction (RT-PCR), with this format

24 allowing rapid and straightforward customisation. Although TACs have shown promising

25 performance relative to conventional microbiology, ${ }^{17}$ our previous experience demonstrated 
medRxiv preprint doi: https://doi.org/10.1101/2020.06.02.20118489; this version posted June 11, 2021. The copyright holder for this preprint (which was not certified by peer review) is the author/funder, who has granted medRxiv a license to display the preprint in perpetuity.

It is made available under a CC-BY 4.0 International license .

26 that a TAC with restricted coverage of common respiratory pathogens had a limited impact

27 on clinical decision making in critically ill patients. ${ }^{18}$ We therefore set out to develop and

28 implement a multi-pathogen array that would have broad applicability for severe pneumonia .

29 


\section{Materials and Methods}

\section{Card development}

33 Organism selection was informed by review the literature concerning organisms found in

34 severe pneumonia ${ }^{1,2,6,13,18,19}$. Details of organism selection and the card layout are shown in

35 supplemental section (Supplemental Figure S1). The card covers 52 organisms (23 bacteria, 2

36 mycobacteria, 6 atypical bacteria, 5 fungi and 16 viruses). The study was undertaken prior to

37 the COVID-19 pandemic starting in 2020.

\section{Card validation}

\section{Technical validation}

41 The card was initially validated against stored extracts, synthetic control plasmids and all

42 available External Quality Assessment (EQA) panels from Quality Control for Molecular

43 Diagnostics (www.qcmd.org) (supplemental results).

\section{Retrospective cohort validation}

46 A retrospective cohort validation was conducting using stored bronchoalveolar lavage (BAL)

47 samples obtained during the twenty four centre VAPrapid trial of a biomarker for the

48 diagnosis of ventilator-associated pneumonia. ${ }^{15}$ VAPrapid centres used semi-quantitative

49 microbiological culture as the reference standard.

50

\section{Prospective evaluation}

\section{Setting}


medRxiv preprint doi: https://doi.org/10.1101/2020.06.02.20118489; this version posted June 11, 2021. The copyright holder for this preprint (which was not certified by peer review) is the author/funder, who has granted medRxiv a license to display the preprint in perpetuity.

It is made available under a CC-BY 4.0 International license .

54 Patients were recruited from a 20-bedded teaching hospital Intensive Care Unit (ICU). The

55 unit is a mixed general medical-surgical unit which supports organ and haematology-

56 oncology services.

57

\section{Recruitment}

59 Between February 2018 and August 2019, prospectively identified patients were eligible for

60 inclusion if they were receiving invasive mechanical ventilation, and if the treating intensive

61 care specialist was performing diagnostic bronchoscopy for suspected pneumonia. Written

62 consent was obtained from the patient or a proxy decision maker. The TAC laboratory team

63 were routinely unavailable from Friday $5 \mathrm{pm}$ to Monday $8 \mathrm{am}$, and also sporadically

64 unavailable due to leave. Patients who were not included in the study because of a lack of

65 TAC laboratory team availability, and those from the month prior and month following the

66 study, formed the comparator group.

67

\section{Sampling procedure}

69 Bronchoscopy was undertaken in accordance with existing unit protocols (supplemental

70 methods).

\section{$71 \quad$ TAC testing}

72 Nucleic acids were extracted from BAL prior to loading on the TAC. The TAC was run by a

73 dedicated laboratory team who did not undertake the conventional PCR or cultures, with

74 blinding also assured by the results of the TAC being obtained before those from

75 conventional microbiology. Full details of the TAC process are included in the supplemental

76 section. 
medRxiv preprint doi: https://doi.org/10.1101/2020.06.02.20118489; this version posted June 11, 2021. The copyright holder for this preprint (which was not certified by peer review) is the author/funder, who has granted medRxiv a license to display the preprint in perpetuity.

It is made available under a CC-BY 4.0 International license .

\section{Conventional microbiological testing}

80 BAL samples were processed according to the UK Standards for Microbiology Investigations

81 (SMI), ${ }^{20}$ with the results of microbiological semi-quantitative culture and conventional PCR

82 for respiratory viruses, herpesvirade and Pneumocystis jirovecii forming the reference

83 standard for the TAC (supplemental methods). As an experimental assay, the results of the

84 TAC were not included in the laboratory information system, blinding the assessors of the

85 reference standard to the TAC results.

\section{Return of results to clinical team}

88 Following review by a consultant clinical scientist, results were returned to the ICU team.

89 Clinical microbiology advice was available 24 hours/day, and patients underwent weekday

90 daily combined ICU-Microbiology multi-disciplinary review in keeping with existing unit

91 practice (weekend microbiology input was available on request). The study did not mandate

92 any course of action by the treating clinical team. Conventional microbiology results were

93 returned to clinicians via the electronic health record; however in practice these were returned

94 after the TAC results.

\section{Outcome measures}

97 The co-primary outcome measures were sensitivity, using conventional microbiology as the

98 reference standard and time to result compared to conventional microbial culture. Time to

99 result for microbial culture was taken as time from completion of lavage to first organism

100 identification, or confirmation of negative growth if no organisms were detected.

101

102 Secondary outcome measures were sensitivity compared to metagenomic microbial

103 sequencing, time to result compared to conventional PCR, days alive and free of antibiotics 
medRxiv preprint doi: https://doi.org/10.1101/2020.06.02.20118489; this version posted June 11, 2021. The copyright holder for this preprint (which was not certified by peer review) is the author/funder, who has granted medRxiv a license to display the preprint in perpetuity.

It is made available under a CC-BY 4.0 International license .

104 (antibiotic-free days, AFDs) in seven and twenty-eight days following lavage and change in 105 antibiotic therapy in the seven days following lavage. Qualitative assessment of whether

106 TAC results impacted on antimicrobial change was assessed by clinical notes review by a

107 member of the study team who was not involved in the decision-making process (VW) .

\section{Statistical analysis}

110 The difference in median time to result for conventional culture and TAC was assessed by

111 Wilcoxon's matched-pairs test. Where conventional PCR failed, or where the lab did not test

112 for the organism, the corresponding tests from the TAC were removed from calculation of

113 diagnostic performance. Indeterminate cultures ('mixed upper respiratory tract flora') were

114 considered negative. A sensitivity analysis, coding failed conventional PCR and organisms

115 not tested 'negative' was also undertaken. Comparisons of distribution of antibiotic free days

116 between TAC and comparator groups was by Mann-Whitney U test, differences in

117 proportions of escalation and de-escalation decisions were assessed by $\mathrm{Chi}^{2}$ test. Analyses

118 were conducted using Prism v9.1 (Graphpad Inc, La Jolla, CA).

\section{Study size}

122 A planned prospective study size of 100 patients evaluated by TAC was selected to balance

123 cost against including sufficient numbers to be able to make a judgement on the card's

124 clinical utility. As the co-primary endpoint was time to result in a real-world setting that had

125 not been previously evaluated, we did not undertake a formal power calculation. 
medRxiv preprint doi: https://doi.org/10.1101/2020.06.02.20118489; this version posted June 11, 2021. The copyright holder for this preprint (which was not certified by peer review) is the author/funder, who has granted medRxiv a license to display the preprint in perpetuity.

It is made available under a CC-BY 4.0 International license.

\section{Ethical and regulatory approvals and funding}

130 The prospective study was approved by the Leeds East Research Ethics Committee

131 (17/YH/0286) Cambridge University Hospitals NHS Foundation Trust was the sponsor, and 132 registered with clinicaltrials.gov (NCT03996330). The assessment of routinely collected data

133 from the comparator group received a consent waiver and was conducted under a protocol

134 approved by the institutional review board (A095506). VAPrapid ${ }^{15}$ was approved by the

135 England and Northern Ireland (13/LO/065) and Scotland (13/SS/0074) National Research

136 Ethics Service committees and sponsored by Newcastle upon Tyne Hospitals NHS

137 Foundation Trust.

139 Results

140 Technical validation

141 Following initial validation against stored DNA extracts and synthetic plasmids, all

142 microorganisms from the Quality Control for Molecular Diagnostics 2018 Sepsis EQA Pilot

143 Study were successfully detected (supplemental Table S1).

145 Retrospective cohort validation

146 The card was tested against the stored samples available from the VAPrapid study ${ }^{15} .128$

147 samples with semi-quantitative culture results were available for analysis. 57 organisms were

148 grown at or above $10^{4}$ colony forming units $(\mathrm{CFU}) / \mathrm{ml}^{20,21}$, with 55 detected by TAC (Table

149 1). The TAC detected a further 295 organisms, including 64 viruses and one atypical

150 organism which the recruiting centres did not test for. Excluding tests for organisms not

151 detectable by culture, 3425 tests on TAC were negative. Sensitivity was 97\% (95\% CI 88-

$152100 \%$ ) and specificity 94\% (95\% CI 93-95\%) (Supplemental Table S2). Organisms detected

153 by both TAC and culture had a median cycles to threshold $(\mathrm{Ct})$ value on the TAC of 29 (IQR

154 26-32 range 20-35) whilst those detected by TAC alone had a median Ct value of 33 (IQR

155 30-35 range 20-40) (supplemental Figure S2). 
medRxiv preprint doi: https://doi.org/10.1101/2020.06.02.20118489; this version posted June 11, 2021. The copyright holder for this preprint (which was not certified by peer review) is the author/funder, who has granted medRxiv a license to display the preprint in perpetuity.

It is made available under a CC-BY 4.0 International license .

157 Prospective evaluation

158 Between January 2018 and September 2019166 ventilated patients were investigated for

159 pneumonia by bronchoscopy, 95 were tested by TAC. Five patients were tested twice by

160 TAC, having suffered a subsequent respiratory deterioration, in total 100 TACs were run. 71

161 patients formed the comparator group (Figure 1). Although inclusion criteria were pragmatic

162 and only required senior clinician suspicion of pneumonia, 92\% of cases met full ECDC

163 criteria for clinical pneumonia (Supplemental Figure S3). Of the eight cases not meeting full

164 ECDC criteria, one lacked a formal radiological report of infiltrates, one had no clinical signs

165 of pneumonia, five had no signs of systemic inflammation and one patient lacked both

166 radiological and systemic inflammation. Table 2 shows participant characteristics of the study

167 population and comparator group.

\section{Time to result}

170 The median difference in time to result between TAC and conventional culture was 51 hours

171 (IQR 41-69 hours $\mathrm{p}<0.0001$ by Wilcoxon matched pairs), the TAC also returned results more 172 rapidly than conventional PCR in almost all cases (Supplemental Figure S4). The minimum

173 TAC time to return was 4 hours, with median time to result 22 hours (IQR 7-24 hours), most

174 of the delays arose from samples taken outside routine working hours, whilst additional

175 delays with conventional PCR results largely reflect laboratory workflow and batching of 176 samples. 
medRxiv preprint doi: https://doi.org/10.1101/2020.06.02.20118489; this version posted June 11, 2021. The copyright holder for this preprint (which was not certified by peer review) is the author/funder, who has granted medRxiv a license to display the preprint in perpetuity.

It is made available under a CC-BY 4.0 International license .

181178 organisms were identified from 100 samples on the TAC (Table 3, Supplemental Table

182 S3). Conventional microbiology detected 66 organisms, with 61 detected by TAC. 27

183 patients had failure of internal control for one or more conventional PCR assays, covering 93

184 organisms. There were no TAC internal control failures and none of the organisms covered

185 by the failed assays were detected on TAC or sequencing (Table 3). Sensitivity and

186 specificity were $92 \%$ (95\% CI 83-98\%) and 97\% (95\% CI 97-98\%) respectively

187 (Supplemental Table S4). Including failed and absent reference standards as 'negative' had

188 minimal effect on diagnostic performance (Supplemental Table S5)

190 Comparison by sequencing

19198 samples were available for sequencing. Metagenomic sequencing revealed 107 organisms,

192100 of which were also detected by TAC (Tables 3, S3).

194 Concerning the 10 organisms detected by conventional microbiology or sequencing but

195 missed by TAC, one organism, that was positive by both culture and sequencing albeit in

196 different patients, was Citrobacter freundii, for which we did not have a sequence on the

197 card. A further five pathogens were detected by sequencing (Staphylococcus aureus,

198 Legionella spp., and Staphylococcus epidermidis) or both culture and sequencing (two E.

199 faecium). Although these five were detected by TAC, they did not pass the internal quality

200 control standards required for reporting and were considered 'negative' results. The

201 remaining three organisms, two rhinovirus by conventional PCR and one Staphylococcus spp.

202 by sequencing, were not detected by TAC at all.

203 One case of Aspergillus fumigatus was detected on the TAC, and although no moulds were

204 cultured, the lavage galactomannan antigen test was highly positive (5.92 optical density

205 index (ODI), laboratory reference range <0.5 ODI). 
medRxiv preprint doi: https://doi.org/10.1101/2020.06.02.20118489; this version posted June 11, 2021. The copyright holder for this preprint (which was not certified by peer review) is the author/funder, who has granted medRxiv a license to display the preprint in perpetuity.

It is made available under a CC-BY 4.0 International license .

207 Quantitation

208 Twenty-five organisms were grown on conventional culture at $\geq 10^{4} \mathrm{CFU} / \mathrm{ml}$, the

209 conventional cut off for quantitative culture of lavage. ${ }^{20,21}$ The median cycles to threshold

210 (Ct) for these organisms on the TAC was 27 (IQR 24-29, range 20-33). In contrast, culturable

211 organisms detected on TAC but not on culture had a median Ct of 32 (IQR 30-34, range 22-

212 38) (supplemental Figure S2) .

213

214 Antibiotic prescribing

215 Patients in the TAC and comparator cohorts had similar severity of illness, severity of

216 respiratory failure and demographic features (Table 2). Patients managed with the TAC had a

217 significantly different distribution of AFDs to the comparator group in the 7 days following

218 bronchoscopy ( $\mathrm{p}=0.02$ by Mann-Whitney U-test), with more AFDs in the TAC cohort. This

219 difference did not retain significance over 28 days (Supplemental Figure S5). Overall 72

$220(76 \%)$ of TAC patients had their antibiotics changed in the seven days following

221 bronchoscopy, with a total of 116 changes made (Table 4). In the comparator group 50

222 (70\%) of patients experienced a total of 65 changes. Whilst $63 \%$ of decisions in the TAC

223 group led to de-escalation, only $37 \%$ of decisions in the comparator group were de-escalation

224 decisions (OR 2.9 (95\% CI 1.5-5.5) p=0.008 by Chi-squared). Decisions which were judged

225 to be related to the TAC result were weighted further towards de-escalation (73\% of all TAC-

226 related changes, Table 4). $11(30 \%)$ of escalations in the TAC group were judged to have

227 been targeted escalations in response to TAC results. In a further six cases negative TAC

228 results prompted investigation for alternative diagnoses. 
medRxiv preprint doi: https://doi.org/10.1101/2020.06.02.20118489; this version posted June 11, 2021. The copyright holder for this preprint (which was not certified by peer review) is the author/funder, who has granted medRxiv a license to display the preprint in perpetuity.

It is made available under a CC-BY 4.0 International license .

\section{Discussion}

232 We demonstrate that a customised molecular diagnostic, designed to meet the needs of a

233 specific clinical setting produced accurate results in a clinically important time-frame and

234 was associated with an increase in antibiotic-free days relative to the comparator group in the

235 week following investigation. Diagnostic performance was similar when assessed in stored

236 samples from multiple centres, indicating a generalisable result.

238 Molecular diagnostic platforms for respiratory infection syndromes have, until recently,

239 largely focussed on viral pathogens. ${ }^{16}$ However, the need to optimise antimicrobial therapy

240 whilst limiting the over-use of these drugs has led to repeated calls for bacterial-focussed

241 diagnostics. ${ }^{16,22}$ TACs have been previously reported for use in pneumonia. ${ }^{18,23,24}$ However,

242 apart from our previous report ${ }^{18}$ that demonstrated limited clinical impact due to restricted

243 organism coverage, none of the other reports have included ventilated patients and were

244 restricted to retrospective analysis of stored samples. Commercial multiple-pathogen arrays

245 that include respiratory bacteria have recently become available. However, most of reports of

246 their use in ventilated patients remain limited to describing diagnostic performance,

247 reporting 'potential' to change antimicrobial therapy rather than impact on clinical

248 practice ${ }^{3,25,26}$. Concerns have been raised about the risks of over-treatment from molecular

249 diagnostics ${ }^{16,27,28}$, whilst conversely promising tests with the potential to change therapy have

250 not always proven this in clinical practice ${ }^{15,18}$. These commercially available assays lack the

251 broad coverage and customisability of the TAC, with consistent concerns raised around

252 limited organism coverage adversely impacting treatment decisions., , $^{3,25,26}$

253

254 Although there is now widespread acceptance of the presence of a respiratory

255 microbiome, ${ }^{29,30}$ the lungs of ventilated patients present a challenge to highly sensitive 
medRxiv preprint doi: https://doi.org/10.1101/2020.06.02.20118489; this version posted June 11, 2021. The copyright holder for this preprint (which was not certified by peer review) is the author/funder, who has granted medRxiv a license to display the preprint in perpetuity.

It is made available under a CC-BY 4.0 International license.

256 molecular diagnostics ${ }^{16,}$. The proximal respiratory tract of ventilated patients becomes rapidly

257 colonised with predominantly Gram negative organisms. ${ }^{31,32}$ This can occur in the absence of

258 infection, and there is a risk that highly sensitive techniques will detect colonising organisms,

259 driving unintended increases in antimicrobial use. ${ }^{16}$ The use of protected lower airway

260 specimens, with growth $\geq 10^{4} \mathrm{CFU} / \mathrm{ml}$ for BAL have been used to distinguish infection from

261 colonisation. $^{21,33}$ We adapted this approach in this study, using the quasi-quantitative $\mathrm{Ct}$

262 value provided by RT-PCR and testing protected bronchoalveolar samples. Using the

263 comparison of the $\mathrm{Ct}$ values of organisms detected by culture and those detected by TAC

264 without culture, we suggest that a $\mathrm{Ct}$ threshold of 32 be used to identify infecting rather than

265 colonising organism (supplemental Figures S2, S6).

267 One of the problems that has beset bacterial diagnostics studies has been the absence of a

268 'gold standard' against which the candidate can be assessed, ${ }^{16,22,34}$ as conventional culture is

269 imperfect. For this study we used a combination of conventional microbiology (culture and

270 viral PCR) and metagenomic sequencing. 10 organisms identified by conventional

271 microbiology or sequencing were not `detected by the TAC. Overall the TAC detected more

272 organisms than either culture or sequencing, reflecting the higher sensitivity of qPCR.

273 However, without a perfect validation method we cannot be certain these were not 'false

274 positives' and have counted them as such for the calculation of specificity. The sequencing

275 and culture results give clinicians considerable confidence in the results provided.

277 The selection of organisms targeted on the card was crucial, and informed by our previous

278 experience where omission of key organisms significantly limited the impact of a similar

279 card. ${ }^{18}$ Given the case mix of our unit, with a high proportion of immunosuppressed patients, 280 we opted to include a number of low pathogenicity organisms, (i.e. coagulase-negative 
medRxiv preprint doi: https://doi.org/10.1101/2020.06.02.20118489; this version posted June 11, 2021. The copyright holder for this preprint (which was not certified by peer review) is the author/funder, who has granted medRxiv a license to display the preprint in perpetuity.

It is made available under a CC-BY 4.0 International license .

281 Staphylococci(CNS), Enterococci and Candida albicans), as well as Herpesviridae, which

282 we routinely tested for. The detection of these organisms can be challenging to interpret ${ }^{35}$,

283 given that many critically ill patients have a degree of immunoparesis, even if not classically

284 immunosuppressed, ${ }^{6,36}$ their significance remains uncertain. As our laboratory routinely

285 reported these organisms on conventional microbiology the clinical team were already

286 confronted with this issue. The inclusion of CNS also aids with the interpretation of the

287 detection of the mecA gene, which is commonly carried by these organisms, thus helping

288 identify MRSA. The lack of CNS on commercial cards has been noted to impair

289 interpretation of mecA in clinical samples ${ }^{25,37}$. However the ready customisability of the

290 TAC would allow units to remove such organisms, as well as add other organisms of local

291 significance as we have done subsequently during the COVID-19 pandemic ${ }^{38}$.

293 The use of a contemporaneous comparator cohort allowed for comparisons of antibiotic

294 prescribing within the context of the implementation of the TAC and any heightened

295 awareness of antimicrobial stewardship it may have engendered. Despite this, the comparator

296 cohort saw a greater proportion of escalation decisions in the week following lavage, and had

297 fewer antibiotic-free days. The lack of difference in AFDs at day 28 is unsurprising, as

298 suspected pneumonia is only one of multiple drivers of antibiotic use. Although the

299 comparator and TAC groups had similar characteristics, our observational design means that

300 we cannot be certain that unmeasured confounders did not contribute to the effects seen.

301

302 This study established a molecular diagnostic test to meet the needs of a particular intensive

303 care unit, and implemented it in the context of a well-established antimicrobial stewardship

304 program. Although the demonstration of similar performance on stored samples from

305 multiple centres is reassuring, the impact on antimicrobial stewardship is likely to be context- 
medRxiv preprint doi: https://doi.org/10.1101/2020.06.02.20118489; this version posted June 11, 2021. The copyright holder for this preprint (which was not certified by peer review) is the author/funder, who has granted medRxiv a license to display the preprint in perpetuity.

It is made available under a CC-BY 4.0 International license .

306

307

308

309

310

311

312

313

314

315

316

317

318

319

320

321

322

323

324

325

326

327

328

329

330

331

332

333

334

335

336

337

338

339

340

341

dependent. Replication in additional settings with distinct approaches to stewardship is

required before we can be certain of its external generalisability, whilst evaluation in a

randomised, controlled trial would help reduce any bias that may have arisen from our

observational study design. We believe this approach represents a promising new approach to

the management of severe pneumonia.

\section{References}

1. Cilloniz C, Ewig S, Polverino E, et al. Microbial aetiology of communityacquired pneumonia and its relation to severity. Thorax. 2011;66(4):340-346.

2. Vincent J-L, Sakr Y, Singer M, et al. Prevalence and Outcomes of Infection Among Patients in Intensive Care Units in 2017. JAMA. 2020;323(15):1478-10.

3. Gadsby NJ, McHugh MP, Forbes C, et al. Comparison of Unyvero P55 Pneumonia Cartridge, in-house PCR and culture for the identification of respiratory pathogens and antibiotic resistance in bronchoalveolar lavage fluids in the critical care setting. Eur J Clin Microbiol Infect Dis. 2019;38(6):1171 $\square 1178$.

4. Arulkumaran N, Routledge M, Schlebusch S, Lipman J, Morris AC. Antimicrobial-associated harm in critical care: a narrative review. Intensive Care Med. January 2020:1-11.

5. Iregui M, Ward S, Sherman G, Fraser VJ, Kollef MH. Clinical Importance of Delays in the Initiation of Appropriate Antibiotic Treatment for Ventilator-Associated Pneumonia. Chest 2002;122(1):262-268.

6. Morris AC. Management of pneumonia in intensive care. J Emerg Crit Care Med. 2018;2:101-101.

7. Rangel-Frausto MS, Pittet D, Costigan M, Hwang T, Davis CS, Wenzel RP. The Natural History of the Systemic Inflammatory Response Syndrome (SIRS). JAMA. 1995;273(2):117-5.

8. Lichtenstein D, Goldstein I, Mourgeon E, Cluzel P, Grenier P, Rouby J-J. Comparative diagnostic performances of auscultation, chest radiography, and lung ultrasonography in acute respiratory distress syndrome. Anesthesiology. 2004;100(1):9-15.

9. Meduri GU, Mauldin GL, Wunderink RG, et al. Causes of fever and pulmonary densities in patients with clinical manifestations of ventilator-associated pneumonia. Chest. 1994;106(1):221-235.

10. Conway Morris A, Kefala K, Wilkinson TS, et al. Diagnostic importance of pulmonary interleukin-1 $\{$ beta\} and interleukin-8 in ventilator-associated pneumonia. Thorax. 2010;65(3):201-207. 
medRxiv preprint doi: https://doi.org/10.1101/2020.06.02.20118489; this version posted June 11, 2021. The copyright holder for this preprint (which was not certified by peer review) is the author/funder, who has granted medRxiv a license to display the preprint in perpetuity.

It is made available under a CC-BY 4.0 International license .

11. Povoa P, Coelho L, Almeida E, et al. C-reactive protein as a marker of ventilator-associated pneumonia resolution: a pilot study. Eur Resp J. 2005;25(5):804812.

12. Pfister R, Kochanek M, Leygeber T, et al. Procalcitonin for diagnosis of bacterial pneumonia in critically ill patients during 2009 H1N1 influenza pandemic: a prospective cohort study, systematic review and individual patient data meta-analysis. Critical Care. 2014;18(2):1-11.

13. Hellyer TP, Morris AC, Mcauley DF, et al. Diagnostic accuracy of pulmonary host inflammatory mediators in the exclusion of ventilator-acquired pneumonia. Thorax. 2015;70(1):41-47.

14. Huang DT, Yealy DM, Filbin MR, et al. Procalcitonin-Guided Use of Antibiotics for Lower Respiratory Tract Infection. N Engl J Med. 2018;379(3):236249.

15. Hellyer TP, McAuley DF, Walsh TS, et al. Biomarker-guided antibiotic stewardship in suspected ventilator-associated pneumonia (VAPrapid2): a randomised controlled trial and process evaluation. Lancet Resp Med. December 2019:1-10.

16. Hanson KE, Azar MM, Banerjee R, et al. Molecular Testing for Acute Respiratory Tract Infections: Clinical and Diagnostic Recommendations From the IDSA's Diagnostics Committee. Clin Infect Dis. 2020;5:401-408.

17. Steensels D, Reynders M, Descheemaeker P, et al. Clinical evaluation of a multi-parameter customized respiratory TaqMan ${ }^{\circledR}$ array card compared to conventional methods in immunocompromised patients. J Clin Virol. 2015;72:36-41.

18. Jones N, Conway Morris A, Curran MD et al. Evaluating the use of a 22pathogen TaqMan array card for rapid diagnosis of respiratory pathogens in Intensive Care. J Med Microbiol. 2020; 69: 971-978.

19. Gadsby NJ, Russell CD, McHugh MP, et al. Comprehensive Molecular Testing for Respiratory Pathogens in Community-Acquired Pneumonia. Clin Infect Dis. 2016;62(7):817-823.

20. Public Health England. Investigation of bronchoalveolar lavage, sputum and associated specimens UK SMI B 57 issue 3.5 (May 2019) (available from https://www.gov.uk/government/publications/smi-b-57-investigation-ofbronchoalveolar-lavage-sputum-and-associated-specimens) accessed 29/4/2021

21. Plachouras D, Lepape A, Suetens C. ECDC definitions and methods for the surveillance of healthcare-associated infections in intensive care units. Intensive Care Med. October 2018:1-3.

22. The Lancet Respiratory Medicine. Pneumonia research: time to fill in the gaps. Lancet Resp Med. 2019;7(12):993.

23 Wolff BJ, Bramley AM, Thurman KA, et al. Improved Detection of Respiratory Pathogens by Use of High-Quality Sputum with TaqMan Array Card Technology. Onderdonk AB, ed. J Clin Microbiol. 2017;55(1):110-121. 
medRxiv preprint doi: https://doi.org/10.1101/2020.06.02.20118489; this version posted June 11, 2021. The copyright holder for this preprint (which was not certified by peer review) is the author/funder, who has granted medRxiv a license to display the preprint in perpetuity.

It is made available under a CC-BY 4.0 International license .

24 Hercik C, Cosmas L, Mogeni OD, et al. A diagnostic and epidemiologic investigation of acute febrile illness (AFI) in Kilombero, Tanzania. Schildgen O, ed. PLOS ONE. 2017;12(12):e0189712-e0189720.

25 Peiffer-Smadja N, Bouadma L, Mathy V, et al. Performance and impact of a multiplex PCR in ICU patients with ventilator-associated pneumonia or ventilated hospital-acquired pneumonia. Crit Care. 2020;24:366

26 Monard C, Pehlivan J, Auger G, et al. Multicenter evaluation of a syndromic rapid multiplex PCR test for early adaptation of antimicrobial therapy in adult patients with pneumonia. Crit Care. 2020;24:434

27. Houben RMGJ, Lalli M, Kranzer K, Menzies NA, Schumacher SG, Dowdy DW. What if They Don't Have Tuberculosis? The Consequences and Trade-offs Involved in False-positive Diagnoses of Tuberculosis. Clin Infect Dis. 2019;68:150156

28. Weinrib DA, Capraro GA. The Uncertain Clinical Benefit of the T2Bacteria Panel. Ann Intern Med. 2019;170:888-889

29. Nolan TJ, Gadsby NJ, Hellyer TP, et al. Low-pathogenicity Mycoplasma spp. alter human monocyte and macrophage function and are highly prevalent among patients with ventilator-acquired pneumonia. Thorax. 2016;71(7):594-600.

30. Zakharkina T, Martin-Loeches I, Matamoros S, et al. The dynamics of the pulmonary microbiome during mechanical ventilation in the intensive care unit and the association with occurrence of pneumonia. Thorax. 2017;72(9):803-810.

31. Ewig S, Torres A, El-Ebiary M, et al. Bacterial colonization patterns in mechanically ventilated patients with traumatic and medical head injury. Incidence, risk factors, and association with ventilator-associated pneumonia. Am J Respir Crit Care Med. 1999;159(1):188-198.

32. Roquilly A, Torres A, Villadangos JA, et al. Pathophysiological role of respiratory dysbiosis in hospital-acquired pneumonia. Lancet Resp Med. 2019;7(8):710-720.

33. Morris AC, Kefala K, Simpson AJ, et al. Evaluation of the effect of diagnostic methodology on the reported incidence of ventilator-associated pneumonia. Thorax. 2009;64(6):516-522.

34. Bhat N, O'Brien KL, Karron RA, Driscoll AJ, Murdoch DR, the Pneumonia Methods Working Group. Use and Evaluation of Molecular Diagnostics for Pneumonia Etiology Studies. Clin Infect Dis. 2012;54(suppl 2):S153-S158.

35. Hagel S, Scherag A, Schuierer L, et al. Effect of antiviral therapy on the outcomes of mechanically ventilated patients with herpes simplex virus detected in the respiratory tract: a systematic review and meta-analysis. Crit Care. 2020;24(1):58410. 
medRxiv preprint doi: https://doi.org/10.1101/2020.06.02.20118489; this version posted June 11, 2021. The copyright holder for this preprint (which was not certified by peer review) is the author/funder, who has granted medRxiv a license to display the preprint in perpetuity.

It is made available under a CC-BY 4.0 International license.

424

425

426

427

428

429

430

431

432

433

434

435

436
36. Morris AC, Datta D, Shankar-Hari M, et al. Cell-surface signatures of immune dysfunction risk-stratify critically ill patients: INFECT study. Intensive Care Med. 2018;44(5):627-635.

37. Webber DM, Wallace MA, Burnham CA, Anderson NW. Evaluation of the BioFire FilmArray Pneumonia Panel for Detection of Viral and Bacterial Pathogens in Lower Respiratory Tract Specimens in the Setting of a Tertiary Care Academic Medical Center. J Clin Microbiol. 2020;58:e00343-20

38. Maes M, Higginson E, Pereira-Dias J, et al. Ventilator-associated pneumonia in critically ill patients with COVID-19. Crit Care. 2021;25(1):25-11. 
medRxiv preprint doi: https://doi.org/10.1101/2020.06.02.20118489; this version posted June 11, 2021. The copyright holder for this preprint (which was not certified by peer review) is the author/funder, who has granted medRxiv a license to display the preprint in perpetuity.

It is made available under a CC-BY 4.0 International license .

437

438

439

\begin{tabular}{|c|c|c|}
\hline Organism detected & $\begin{array}{c}\text { Frequency } \\
\text { of growth }\left(\geq 10^{\wedge} 4 \mathrm{CFU} / \mathrm{ml}\right) \\
\text { on conventional culture }\end{array}$ & $\begin{array}{c}\text { Frequency } \\
\text { by TAC (numbers } \\
\text { detected at } \mathrm{Ct} \leq 32 \\
\text { shown in brackets) }\end{array}$ \\
\hline \multicolumn{3}{|l|}{ Gram negative } \\
\hline Acinetobacter baumannii complex & 2 & $4(3)$ \\
\hline Enterobacter aerogenes & 1 & $0^{*}$ \\
\hline Enterobacter cloacae & 2 & $7(5)$ \\
\hline Enterococcus faecalis & 0 & $2(1)$ \\
\hline Enterococcus faecium & 2 & $15(9)$ \\
\hline Escherichia coli & 6 & $44(16)$ \\
\hline $\begin{array}{l}\text { Enterobacteriaceae } \\
\text { (not further specified) }\end{array}$ & 0 & $7(3)$ \\
\hline Haemophilus influenzae & 3 & $23(19)$ \\
\hline Haemophilus haemolyticus & 1 & $0^{*}$ \\
\hline Klebsiella pneumoniae & 2 & $13(6)$ \\
\hline $\begin{array}{l}\text { Legionella spp. } \\
\text { (non-pneumophilia) }\end{array}$ & 0 & $1(1)$ \\
\hline Morexella catharralis & 1 & $5(4)$ \\
\hline Morganella morganii & 0 & $1(1)$ \\
\hline Mycoplasma pneumoniae & 0 & $1(1)$ \\
\hline Neisseria meningitidis & 0 & $1(1)$ \\
\hline Proteus spp. ${ }^{\#}$ & 2 & $7(5)$ \\
\hline Pseudomonas aeruginosa & 5 & $10(9)$ \\
\hline Serratia marcescens & 1 & $5(3)$ \\
\hline \multicolumn{3}{|l|}{ Gram positive } \\
\hline Staphylococcus aureus & 21 & $32(28)$ \\
\hline Staphylococcus epidermidis & 0 & $12(3)$ \\
\hline $\begin{array}{l}\text { Other coagulase negative } \\
\text { Staphylococcus }\end{array}$ & 0 & $9(1)$ \\
\hline Stenotrophomonas maltophilia & 2 & $11(5)$ \\
\hline Streptococcus pneumoniae & 0 & $15(10)$ \\
\hline Streptococcus pyogenes & 0 & $1(1)$ \\
\hline $\begin{array}{l}\text { Streptococcus spp. } \\
\text { (not further specified) }\end{array}$ & 0 & $37(25)$ \\
\hline \multicolumn{3}{|l|}{ Fungi } \\
\hline Aspergillus fumigatus. & 0 & $1(1)$ \\
\hline Candida albicans & 4 & $17(7)$ \\
\hline Candida spp. & 2 & $5(3)$ \\
\hline \multicolumn{3}{|l|}{$\begin{array}{l}\text { Viruses (not tested for by } \\
\text { conventional microbiology) }\end{array}$} \\
\hline Coronavirus OC43 & & $1(1)$ \\
\hline Cytomegalovirus & & $6(1)$ \\
\hline Epstein-Barr Virus & & $15(3)$ \\
\hline Herpes simplex virus & & $34(26)$ \\
\hline Influenza A & & $3(3)$ \\
\hline Parainfluenza virus & & $1(1)$ \\
\hline Rhinovirus & & $4(4)$ \\
\hline
\end{tabular}

\section{Table 1:culture of microorganisms from 128 stored samples from the VAPrapid clinical} trial $^{15}$ and results from the TAC. CFU- colony forming units/ml, Ct -cycles to crossing threshold.

*not on card

\# culture reported as Proteus mirabilus, on TAC reported as genus-level Proteus spp. 
medRxiv preprint doi: https://doi.org/10.1101/2020.06.02.20118489; this version posted June 11, 2021. The copyright holder for this preprint (which was not certified by peer review) is the author/funder, who has granted medRxiv a license to display the preprint in perpetuity.

It is made available under a CC-BY 4.0 International license .

\begin{tabular}{|c|c|c|}
\hline Parameter & $\begin{array}{l}\text { TAC patients } \\
\text { (95 patients) }\end{array}$ & $\begin{array}{c}\text { Comparator group } \\
\text { (71 patients) }\end{array}$ \\
\hline Median age (range) & $60(21-86)$ & $62(18-83)$ \\
\hline n (\%) female & $41(43 \%)$ & $27(38 \%)$ \\
\hline $\begin{array}{l}\text { Median (IQR) functional } \\
\text { comorbidity index }\end{array}$ & $1(2)$ & $1(2)$ \\
\hline $\begin{array}{l}\text { n }(\%) \text { with community- } \\
\text { acquired pneumonia } \\
\text { n }(\%) \text { hospital-acquired } \\
\text { pneumonia }\end{array}$ & $\begin{array}{l}34(36 \%) \\
61(64 \%)\end{array}$ & $\begin{array}{l}20(28 \%) \\
51(72 \%)\end{array}$ \\
\hline $\begin{array}{l}\text { of HAP n (\%) ventilator- } \\
\text { associated }\end{array}$ & $24(39 \%)$ & $27(52 \%)$ \\
\hline $\begin{array}{l}\text { Median (IQR) APACHE II } \\
\text { score on admission }\end{array}$ & $16(10)$ & $16(9)$ \\
\hline $\begin{array}{l}\% \text { receiving antibiotics at time } \\
\text { of lavage }\end{array}$ & $82 \%$ & $96 \%$ \\
\hline $\begin{array}{l}\text { Median (IQR) } \mathrm{FiO}_{2} \text { prior to } \\
\text { bronchoscopy }\end{array}$ & $0.5(0.25)$ & $0.5(0.30)$ \\
\hline $\begin{array}{l}\text { Median (IQR) white cell count } \\
\left(\mathrm{x} 10^{9} / \mathrm{L}\right)\end{array}$ & $10.5(12.4)$ & $10.7(9.5)$ \\
\hline $\begin{array}{l}\text { Median (IQR) neutrophil count } \\
\left(\times 10^{9} / \mathrm{L}\right)\end{array}$ & $8.6(11.5)$ & $8.8(8.63)$ \\
\hline $\begin{array}{l}\text { Median (IQR) C-reactive } \\
\text { protein concentration } \\
(\mathrm{mg} / \mathrm{L})\end{array}$ & $198(153)$ & $146(154)$ \\
\hline 28-day mortality n (\%) & $30(32 \%)$ & $21(30 \%)$ \\
\hline
\end{tabular}

Table 2: Baseline characteristics of study population. APACHE II, acute physiology and 
medRxiv preprint doi: https://doi.org/10.1101/2020.06.02.20118489; this version posted June 11, 2021. The copyright holder for this preprint (which was not certified by peer review) is the author/funder, who has granted medRxiv a license to display the preprint in perpetuity.

It is made available under a CC-BY 4.0 International license .

\begin{tabular}{|c|c|c|c|}
\hline Organism detected & $\begin{array}{c}\text { Frequency } \\
\text { (by conventional } \\
\text { microbiology) }\end{array}$ & $\begin{array}{c}\text { Frequency } \\
\text { (by TAC) }\end{array}$ & $\begin{array}{c}\text { Frequency } \\
\text { (by sequencing) }\end{array}$ \\
\hline \multicolumn{4}{|l|}{ Bacteria } \\
\hline Citrobacter freundii & $1 *$ & 0 & $1 *$ \\
\hline Enterobacter cloacae & 2 & 8 & 3 \\
\hline Enterococcus faecalis & 0 & 3 & 0 \\
\hline Enterococcus faecium & 3 & 7 & 7 \\
\hline Escherichia coli & 6 & 14 & 6 \\
\hline Klebsiella pneumoniae & 3 & 5 & 3 \\
\hline $\begin{array}{l}\text { Enterobacteriaceae } \\
\text { (not further specified) }\end{array}$ & 0 & 1 & 2 \\
\hline Haemophilus influenzae & 0 & 3 & 2 \\
\hline Legionella pneumophilia & $1 * *$ & 1 & 1 \\
\hline $\begin{array}{l}\text { Legionella spp. } \\
\text { (non-pneumophilia) }\end{array}$ & 0 & 2 & 2 \\
\hline Morexella catharralis & 0 & 1 & 0 \\
\hline Mycoplasma pneumoniae & 0 & 1 & 1 \\
\hline Proteus spp. & 0 & 2 & 0 \\
\hline Pseudomonas aeruginosa & 2 & 5 & 4 \\
\hline Serratia marcescens & 1 & 3 & 0 \\
\hline Staphylococcus aureus & 2 & 8 & 8 \\
\hline Staphylococcus epidermidis & 0 & 9 & 2 \\
\hline $\begin{array}{l}\text { Other coagulase negative } \\
\text { Staphylococcus }\end{array}$ & 0 & 1 & 2 \\
\hline $\begin{array}{l}\text { Other Staphylococcus spp. } \\
\text { (not further specified) }\end{array}$ & 0 & 0 & 1 \\
\hline Stenotrophomonas maltophilia & 2 & 4 & 2 \\
\hline Streptococcus pneumoniae & 1 & 9 & 6 \\
\hline Streptococcus pyogenes & 0 & 1 & 0 \\
\hline $\begin{array}{l}\text { Streptococcus spp. } \\
\text { (not further specified) }\end{array}$ & 0 & 23 & 10 \\
\hline Mixed upper respiratory tract flora & 1 & N/A & N/A \\
\hline \multicolumn{4}{|l|}{ Fungi } \\
\hline Aspergillus spp. & $0 * * *$ & 1 & 0 \\
\hline Candida albicans & 1 & 12 & 10 \\
\hline Candida spp. & 0 & 1 & 1 \\
\hline Pneumocystis jirovecii & 4 & 4 & 3 \\
\hline \multicolumn{4}{|l|}{ Viruses } \\
\hline Coronavirus $^{\#}$ & 0 & 3 & 1 \\
\hline Cytomegalovirus & 5 & 7 & 4 \\
\hline Epstein-Barr Virus & 1 & 6 & 1 \\
\hline Herpes simplex virus & 7 & 11 & 7 \\
\hline Human metapneumovirus & 1 & 1 & 1 \\
\hline Influenza A & 7 & 7 & 5 \\
\hline Influenza B & 3 & 3 & 2 \\
\hline Parainfluenza virus & 4 & 4 & 4 \\
\hline Rhinovirus & 8 & 8 & 7 \\
\hline
\end{tabular}


medRxiv preprint doi: https://doi.org/10.1101/2020.06.02.20118489; this version posted June 11, 2021. The copyright holder for this preprint (which was not certified by peer review) is the author/funder, who has granted medRxiv a license to display the preprint in perpetuity.

It is made available under a CC-BY 4.0 International license.

473

\begin{tabular}{|c|c|c|c|c|}
\hline \multirow{2}{*}{$\begin{array}{l}\text { Antibiotic } \\
\text { change }\end{array}$} & \multirow[t]{2}{*}{ Details of change } & \multicolumn{2}{|c|}{ TAC cohort } & \multirow{2}{*}{$\begin{array}{c}\text { Comparator } \\
\text { cohort }\end{array}$} \\
\hline & & TAC-related & TAC-unrelated & \\
\hline \multirow{7}{*}{$\begin{array}{l}\text { De- } \\
\text { escalation }\end{array}$} & Stopping macrolides & 14 & 3 & 6 \\
\hline & $\begin{array}{l}\text { Stopping carbapenem or anti-pseudomonal } \\
\text { penicillin }\end{array}$ & 10 & 14 & 10 \\
\hline & $\begin{array}{l}\text { Narrowing from } \\
\text { carbapenem/antipseudomonal penicillin to } \\
\text { narrower spectrum penicillin }\end{array}$ & 7 & 0 & 1 \\
\hline & Stopping cotrimoxazole & $6^{*}$ & 1 & 0 \\
\hline & Stopping antivirals & 3 & 0 & 0 \\
\hline & Stopping aminoglycosides & 2 & 3 & 0 \\
\hline & Stopping other agents & 6 & 4 & 7 \\
\hline \multirow[t]{5}{*}{ Escalation } & Start antivirals & 7 & 0 & 1 \\
\hline & Start or broaden antifungals cover & 3 & $7^{* *}$ & 6 \\
\hline & $\begin{array}{l}\text { Broadened Gram negative cover (add anti- } \\
\text { pseudomonal penicillin, aminoglycoside or } \\
\text { carbapenem) }\end{array}$ & 3 & 16 & 28 \\
\hline & Add glycopeptide & 4 & 1 & 5 \\
\hline & Add cover for atypical organism & 1 & 1 & 1 \\
\hline
\end{tabular}

Table 4: Detail of changes in antibiotic therapy in the seven days following lavage in the TAC and comparator cohorts. Changes judged to be TAC-related are shown in the lefthand sub-column for the TAC group. Several patients had more than one change in antibiotic therapy. *includes two de-escalations to prophylactic dose, ** includes two escalations from prophylactic to therapeutic dose. 
medRxiv preprint doi: https://doi.org/10.1101/2020.06.02.20118489; this version posted June 11, 2021. The copyright holder for this preprint (which was not certified by peer review) is the author/funder, who has granted medRxiv a license to display the preprint in perpetuity.

It is made available under a CC-BY 4.0 International license.

$481 \quad$ Figure legends

482

483

484

485

486

Figure 1: Study flow diagram

487

488

489

490

491

Figure 2: Distribution of days alive and free of antibiotics in the seven days following

492

*included in comparator group as TAC laboratory team not available to process samples

493

bronchoscopy and lavage in the TAC and comparator cohorts. Following first lavage

494

only for patients who had more than one BAL during ICU admission. Numbers in each

495 category and percentage shown below graph, $\mathrm{p}$ value by Mann-Whitney $\mathrm{U}$ test. 


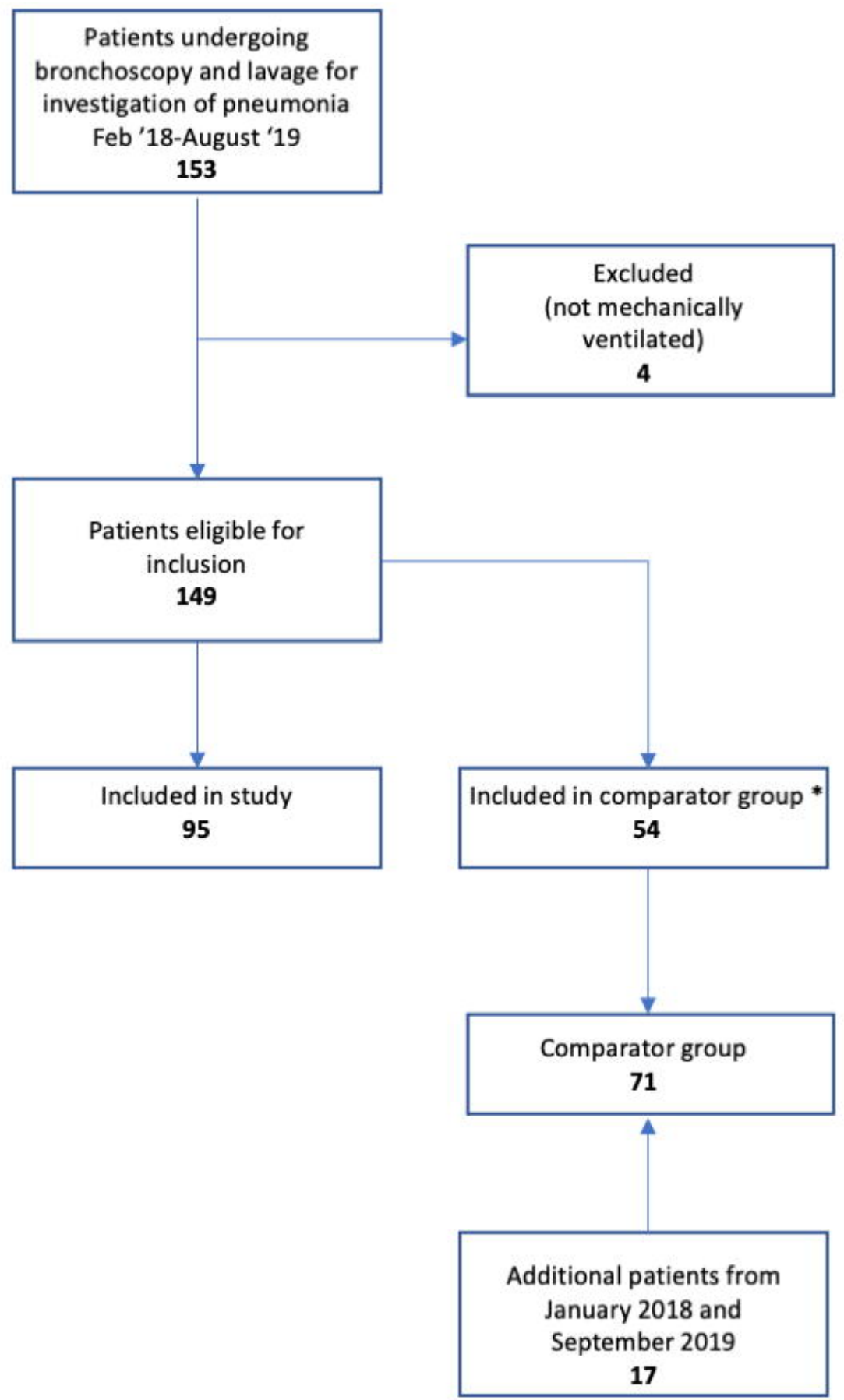




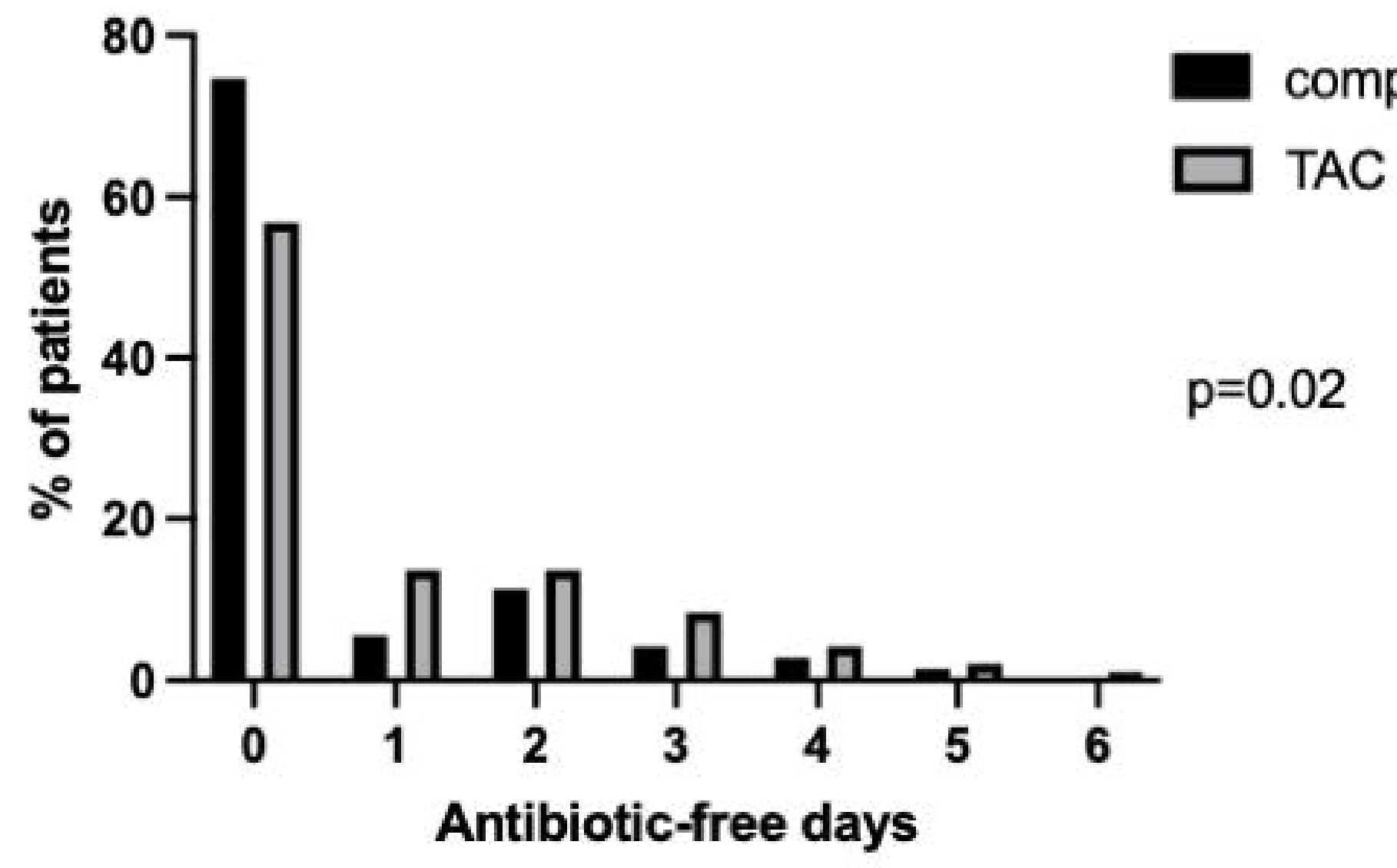

Comp
(n) 53
4
$\begin{array}{lll}8 & 3 & 2\end{array}$
10

TAC
(n) 54
13
13
8
4
21 